\title{
The lichens of Lord Howe Island. 1. Introduction and the genus Pertusaria (Pertusariaceae)
}

\author{
Alan W. Archer \& John A. Elix
}

\begin{abstract}
Archer, Alan W. ${ }^{1}$ E Elix, John A. ${ }^{2}\left({ }^{1}\right.$ National Herbarium of New South Wales, Royal Botanic Gardens, Sydney, NSW, Australia 2000; ${ }^{2}$ Department of Chemistry, The Faculties, Australian National University, Canberra, ACT, Australia 0200) 1994. The lichens of Lord Howe Island. 1. Introduction and the genus Pertusaria (Pertusariaceae). Telopea 6(1): 9-30. The historical records of lichens of Lord Howe Island are discussed and an account is given of the lichen genus Pertusaria on Lord Howe Island. Twenty species are found there, six of which are new: Pertusaria howeana Archer \& Elix, P. lordhowensis Archer \& Elix, P. malabara Archer \& Elix, P. maritima Archer \& Elix, P. miniatescens Archer \& Elix and P. puffina Archer \& Elix. Pertusaria subventosa Malme is also reported from New Zealand. A key to the species on Lord Howe Island is presented. Pertusaria dehiscens Müll.Arg. var. alba Müll.Arg., P. dehiscens Müll.Arg. var. depressior Müll.Arg. and P. sulphurescens Müll.Arg. are reported as synonyms of $P$. dehiscens Müll.Arg.
\end{abstract}

\section{Introduction}

Lord Howe Island and satellite islets (the Admiralty Islands, Rabbit Island, Mutton Bird Island, Balls Pyramid, etc.) are isolated volcanic outcrops in the South Pacific Ocean between longitudes $159^{\circ} 02^{\prime} 12^{\prime \prime}$ and $159^{\circ} 06^{\prime} 18^{\prime \prime} \mathrm{E}$ and latitudes $31^{\circ} 30^{\prime} 42^{\prime \prime}$ and $31^{\circ} 36^{\prime} 00^{\prime \prime} \mathrm{S}$. The islands are the emergent portions of a large, nearly truncated seamount. This seamount sits on the western edge of the Lord Howe Rise - an undersea volcanic plateau some $300 \mathrm{~km}$ wide and 2,000 km long, extending from New Zealand to the Chesterfield Reefs, midway between New Caledonia and the Queensland coast. Lord Howe Island lies approximately $700 \mathrm{~km}$ north-east of Sydney and $1250 \mathrm{~km}$ north-west from the northern tip of New Zealand.

Lord Howe Island (Figure 1) is an Australian territory, under the administrative control of New South Wales. The island is roughly crescent-shaped, approximately $12 \mathrm{~km}$ long and $2.8 \mathrm{~km}$ wide, totalling 1,455 ha in area and almost completely volcanic in origin, with basalts and breccias the major rock types. Geologically Lord Howe Island is now considered to be the eroded remnant of a large shield volcano active during the Pleiocene epoch, some 7 million years ago. Several volcanic periods are believed responsible for different parts of the Island, but the two present mountains, Mt Gower and Mt Lidgbird, represent the most recent volcanic phase (6.4 million years ago). The low-lying central part of Lord Howe Island is covered by a coarse, marine calcarenite of late Pleistocene origin (McDougall, Embleton \& Stone 1981).

Much of Lord Howe Island is mountainous or hilly country. The southern half of the island is dominated by the twin peaks of Mt Gower, $875 \mathrm{~m}$, and Mt Lidgbird, $777 \mathrm{~m}$. The volcanic hills in the northern and central parts of the island are lower - Mt Eliza is only $148 \mathrm{~m}$ and Intermediate Hill $250 \mathrm{~m}$ above sea level. Between the northern and southern hills there are low-lying sand and sedimentary deposits. The coastline 


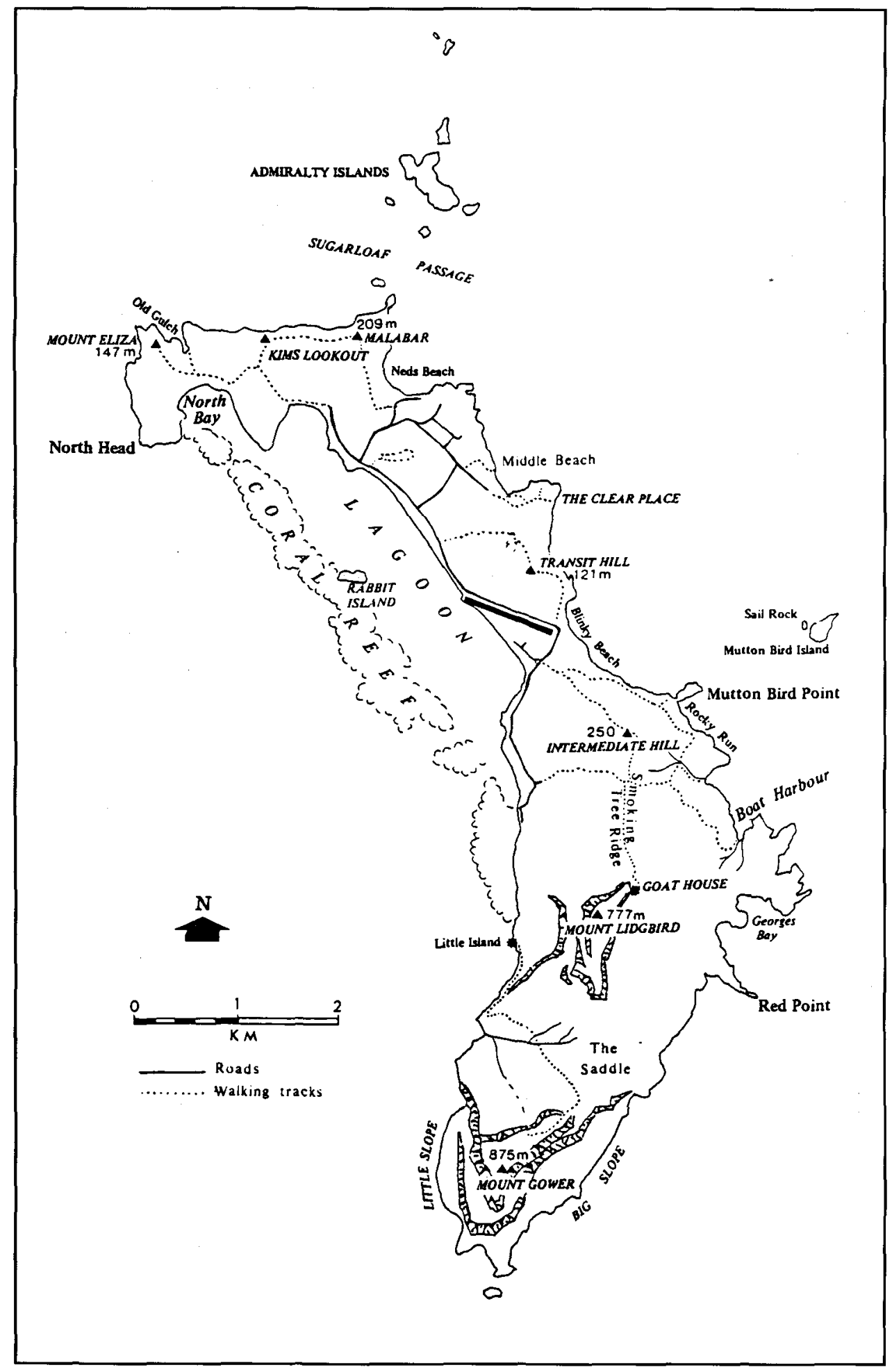

Figure 1. Lord Howe Island. 
varies from the large shallow reef-fringed lagoon with white sandy beaches on the western side of the island to small sandy bays (e.g. Neds Beach) or sheer black cliffs of basalt up to $200 \mathrm{~m}$ high (Malabar) (Hutton 1985).

The climate of Lord Howe Island is subtropical with no extremes of temperature, no real seasonal pattern and moderate relative humidity (70-78\%). Mean monthly temperature fluctuates from minima near $13^{\circ} \mathrm{C}$ (in winter) to maxima near $25^{\circ} \mathrm{C}$ (in summer) and the daily range is rarely more than $8^{\circ} \mathrm{C}$. Rainfall (mean annual precipitation $1675 \mathrm{~mm}$ ) occurs throughout the year with a winter maximum (June average of $187 \mathrm{~mm}$ ) and summer minimum (February average of $113 \mathrm{~mm}$ ). The summers are actually drier than the figures indicate, but erratic summer rain depressions (up to $300 \mathrm{~mm}$ in a month) boost the average monthly figures.

\section{History of lichenological investigations}

Lord Howe Island was discovered in 1788 by Lieutenant H. Lidgbird Ball, of H.M.S. Supply, while on his way from Port Jackson to establish a penal colony on Norfolk Island. The island had remained undiscovered by the Polynesians on their migrations throughout the Pacific and was uninhabited. The first settlers arrived in 1834 and grew fruit and vegetables which they traded with whalers.

The island has been visited by a number of scientific expeditions in the course of its short history, but few of the early expeditions contributed greatly to the knowledge of the lichen flora. The most important collections were made by Charles Moore, the then director of the Botanic Gardens in Sydney, who, with his assistant Mr Carron, visited the Island in 1869 . They formed part of an observation party sent to report on the Island by the government of New South Wales, together with the water police magistrate, P. L. Cloete, sent to investigate a murder. The first lichens from Lord Howe Island to be determined were reported by Krempelhuber (1881), who recorded five species from collections made in the main by Fullagar and forwarded. to him by Baron Ferdinand von Mueller (Royal Botanic Gardens, Melbourne). The first new lichen species reported from Lord Howe Island was Pseudocyphellaria poculifera (Müll. Arg.) D. Gall. \& P. James [as Sticta poculifera Müll. Arg.], described. by J. Müller of Argau (Müller 1882) from a collection made by de Camara, again forwarded to Europe by F. Mueller. Subsequently Moore's lichen collections were examined by A. Zahlbruckner in Vienna, who recorded a total of 12 taxa from the Island (Zahlbruckner 1896).

A combined list is presented here using currently accepted names for taxa followed, where appropriate, by the synonyms used by Krempelhuber, J. Müller and Zahlbruckner in brackets. These recorded taxa have not yet been verified. The species list included:

Cladonia furcata (Huds.) Schrad. [Cladonia furcata var. tenuicaulis Müll. Arg.]

Heterodea muelleri Nyl.

Lobaria querzicans Michx. [Sticta querzicans Ach.]

Pseudocyphellaria aurata (Sm.) Vain. [Sticta aurata Sm.]

Pseudocyphellaria carpoloma (Del.) Vain. [Stictina carpoloma Nyl.]

Pseudocyphellaria freycinetii (Del.)Malme [Sticta freycinetii Del.]

Pseudocyphellaria mooreana (Zahlbr.)Imshaug [Sticta mooreana Zahlbr.] 
Pseudocyphellaria psilophylla Müll. Arg.) D. Gall. \& P. James [Sticta psilophylla Müll. Arg.]

Ramalina peruviana Ach. [Ramalina javanica Nyl.]

Ramalina subfraxinea Nyl. [Ramalina complanata Ach.]

Sphaerophorus melanocarpus (Sw.)DC. in Lamy \& DC. [Sphaerophoron compressum Ach. var. candidum Müll. Arg.]

Sticta latifrons A. Rich., [Sticta sinuosa var. macrophylla Bab.]

Usnea dasypoga (Ach.) Nyl. [Usnea barbata var. dasypoga Fr.]

Usnea vrieseana Mont. \& v. d. Bosch.

Xanthoparmelia tasmanica (Taylor) Hale [Parmelia stramineonitens Zahlbr.]

Subsequently Edwin Cheel (Botanic Gardens, Sydney) referred to several lichens from Lord Howe Island (Cheel 1906, 1913) but no new records were included. More recently Pickard (1973) published an annotated bibliography of all the botanical literature on Lord. Howe Island including 9 references to lichens and these have been summarised above. From the collections housed in NSW and CBG it is apparent that lichens have been collected on Lord Howe Island by C. Hedley and W. S. Dunn [1908], W. W. Watts [1911 - who also made an important collection of bryophytes], J. Stovold [1924], J. Pickman [1978], D.H. Vitt [1981]. Only one species of Pertusaria has been described from Lord Howe Island, Pertusaria sublacerans Archer (Archer 1991), the specimens of which were collected by W.W. Watts in 1911.

\section{Principal vegetation formations}

The vegetation of Lord Howe Island (Pickard 1981) can be divided into four major formations namely: pastures and foreshores, and three broad types of sub-tropical rainforest: lowland 'dry' forests, lowland sheltered forests and the mountain rainforest. Brief notes are given below for these, together with the dominant lichen genera occurring in each formation.

Pastures and foreshores: Here old fence posts are colonised by a few corticolous lichens (Dirinaria, Lecanora, Pertusaria sp.). Remnant Cryptocarya triplinervis (blackbutt) trees, which occur in scattered stands, are much better substrates, with more species present and larger populations of lichens. Basaltic rock surfaces in pasture and exposed ridges (e.g. ridge to Malabar Hill) are very interesting substrates and lichen communities here include representatives of Parmotrema, Xanthoparmelia and Xanthoria plus a variety of microlichen genera including Lecanora and Pertusaria. Interestingly the outcrops of calcarenite near Neds Beach appear to be almost devoid of lichens.

Lowland dry forests: Such forests occur in exposed low altitude areas and are dominated by Cryptocarya triplinervis, Ficus macrophylla subsp. columnaris (banyan) and dense thickets of the endemic palms Howea fosteriana and $\mathrm{H}$. belmoreana. These forests are quite good lichen habitats: the richest substrates are the upper trunks and canopy branches of Cryptocarya and base of the trunks and dead wood on Howea palms. The macrolichen genera Dirinaria, Physcia, Pyxine and Parmotrema are prominent along with the crustose taxa Caloplaca, Graphidaceae, Pertusaria and Buellia. 
Lowland sheltered forests: Lowland sheltered forests occur in protected sites with well watered basalt soils, and dominant phanerogam species include Bubbia howeana, Cleistocalyx fullageri, Atractocarpus stipularis and Chionanthus quadristamineus. Such forests are characteristic of the slopes of Mt Gower and Mt Lidgbird, the western slope of Intermediate Hill and Malabar Ridge near Kims Lookout. The tree branches in the canopy are rich lichen habitats, with Pannaria, Pseudocyphellaria, Heterodermia and Bulbothrix species being prominent. The endemic pandanus, Pandanus forsteri, is common along creek beds in such habitats and its prodigious prop roots (sometimes to $18 \mathrm{~m}$ high) are commonly covered with lichens, particularly Graphidaceae. Basalt rocks in such areas are also interesting lichen substrates often supporting large colonies of Letronitia, Lecanora, Buellia and Pertusaria species.

Mountain rainforest: As a consequence of the higher humidity and rainfall on $\mathrm{Mt}$ Lidgbird and Mt Gower, the summit areas (particularly on the latter) are covered with a unique miniature rainforest. The forest consists of a dense growth of small trees, bushes, palms and tree ferns rarely more than $4 \mathrm{~m}$ in height, the trunks and branches of which are densely encrusted with epiphytic ferns, mosses, lichens and orchids. Many of the Island' s unique plants grow in this forest, including the palms Heyscepe canterburyana, Lepidorrhachis mooreana, Dracophyllum fitzgeraldii and Negria rhabdothamnoides. Moisture tolerant lichen genera abound, including large colonies of Pseudocyphellaria, Leptogium, Pannariaceae and Sticta in the wetter areas, while the canopy branches provide a rich substrate for crustose lichens, including many species of Graphidaceae, Pyrenula, Clathoporina and Megalospora. One of the most striking lichens of the forest is Pseudocyphellaria poculifera, with its brilliantly yellow and emerald green (when wet) thallus. This species commonly inhabits the trunks and branches of many trees and shrubs.

\section{Materials and methods}

This account is based mainly on specimens collected by one of us (J.A.E.) on Lord Howe Island in June 1992 and an examination of type specimens from H-NYL, G, NSW, TUR-V, S and WELT. The techniques used for the examination of the specimens have been described previously (Archer 1991); in addition, the chemistry was determined by liquid chromatography (Elix \& Venables 1993). Sections of verrucae were mounted in water for measurement of spore size; the spore dimensions quoted are those of mature spores, although smaller, immature spores may also be present. The figures illustrate holotypes.

\section{Results}

Pertusaria asperata Archer

(Archer \& Elix 1992: 417)

Type: New South Wales: Myall River State Forest, on sandstone rock, by side of track, near Crawford River, c. $10 \mathrm{~km} \mathrm{~W}$ of Bulahdelah, $32^{\circ} 25^{\prime} \mathrm{S}, 152^{\circ} 06^{\prime} \mathrm{E}$, alt. c. $50 \mathrm{~m}$, A.Archer P188, 20 June 1991 (holo NSW).

Thallus off-white to pale greyish white, thin, areolate and cracked, surface subtuberculate and dull, lacking isidia and soredia, saxicolous; apothecia verruciform, concolorous with the thallus, numerous, scattered, rarely confluent, flattened hemispherical, concave above, constricted at the base, $0.8-1.5 \mathrm{~mm}$ diam.; ostioles conspicuous, dark brown, 1 per verruca; spores 8 per ascus, ellipsoid to subfusiform, smooth, irregularly biseriate, $112-125 \mu \mathrm{m}$ long, $37-50 \mu \mathrm{m}$ wide. 
Chemistry: K-, KC-, C-, Pd-; lichexanthone, stictic and constictic acids.

Pertusaria asperata is characterised by the eight biseriate subfusiform spores and the presence of lichexanthone and stictic acid. It somewhat resembles Pertusaria petrophyes Knight but is distinguished from that species by the spore size and chemistry. Pertusaria asperata is an uncommon species found in New South Wales and Lord Howe Island, where it occurs on basalt rocks.

Also examined: Lord Howe Island: Max Nicholls Track, $31^{\circ} 31^{\prime} 08^{\prime \prime} \mathrm{S}, 159^{\circ} 03^{\prime} 03^{\prime \prime} \mathrm{E}$, alt. $50 \mathrm{~m}$, in dry lowland forest, Elix 32720, June 1992 (ANUC); along ridge to Malabar Hill, $31^{\circ} 31^{\prime} 16^{\prime \prime} \mathrm{S}, 159^{\circ} 03^{\prime} 50^{\prime \prime} \mathrm{E}$, alt. $80 \mathrm{~m}$, in dense shrubby vegetation, Elix 32973, June 1992 (ANUC).

Pertusaria dehiscens Müll. Arg. (Müller 1884: 349)

Type: Brazil: Apiahy [Apiai], Puiggari 499 p.p., vii.1882 (G-lectotype, fide M. Oshio 1978)[previously reported as Puiggari s.n. (Archer 1991)]; Puiggari 2197 p.p. (Gsyntype).

Pertusaria dehiscens var. alba Müll. Arg. (Müller 1884: 349)

Type: Brazil: Apiahy, Puiggari 2197 p.p. (G-syntype).

Pertusaria dehiscens var. depressior Müll. Arg. (Müller 1884: 349)

Type: Brazil: Apiahy, Puiggari 499 p.p. (G-syntype); India, Neilgherries [Nilgiri Hills, ca. $250 \mathrm{~km}$ SSW of Bangalore], Ziegler s.n. (G-syntype).

Pertusaria sulphurescens Müll. Arg. (Müller 1884: 349)

Type: Brazil: Apiahy, Puiggari 2197 p.p., July 1881(G-holotype).

Thallus pale to dark olive green, wrinkled and cracked, lacking isidia and soredia, surface dull, corticolous; apothecia verruciform, conspicuous, numerous, concolorous with the thallus, flattened hemispherical, $0.8-1.5 \mathrm{~mm}$ diam.; ostioles black, punctiform, 2-5 per verruca, in a hyaline zone, the zone becoming conspicuous, deeply concave and almost disciform, to $0.8 \mathrm{~mm}$ diam.; spores 8 per ascus, biseriate, smooth, fusiform, 100-140(-150) $\mu \mathrm{m}$ long, 35-50 $\mu \mathrm{m}$ wide.

Chemistry: K-, KC-, C-, Pd-; lichexanthone and stictic and constictic acids.

Pertusaria dehiscens is characterised by the conspicuously depressed ostioles, the eight biseriate spores and the chemistry. The multiple black ostioles in a concave hyaline zone and the fusiform spores distinguish Pertusaria dehiscens from the chemically similar, saxicolous Pertusaria asperata which has single dark brown ostioles, not in a hyaline zone, and ellipsoid to subfusiform spores. The three additional synonymous taxa listed above are chemically and morphologically identical to Pertusaria dehiscens. The species also occurs in Queensland, New South Wales, Norfolk Island and India and Brazil.

Also examined: Lord Howe Island: along track to Mutton Bird Point, 31 $32^{\prime} 45^{\prime \prime} \mathrm{S}$, $159^{\circ} 05^{\prime} 00^{\prime \prime} \mathrm{E}$, alt. $60 \mathrm{~m}$, on dead canopy branches in dry lowland forest with basalt outcrops, Elix 32786, June 1992 (ANUC).

Pertusaria elliptica Müll. Arg.

(Müller 1895: 635)

Type: Queensland: Goodna, Shirley 1754 p.p.,1893 (holo G).

Thallus off-white or pale grey to pale olive green, thin, surface smooth or slightly rough and dull, corticolous; apothecia verruciform, conspicuous, scattered, slightly 
flattened hemispherical, rounded or elongated or irregular in outline, becoming constricted at the base and concave above, $0.5-1.5 \mathrm{~mm}$ diam.; ostioles conspicuous, black, sometimes in a grey translucent zone, 1-2 per verruca; spores 3-4 per ascus, uniseriate, elongate ellipsoid to subfusiform, rough, 80-110 $\mu \mathrm{m}$ long, 30-45 $\mu \mathrm{m}$ wide.

Chemistry: K-, KC-, C-, Pd-; 2,5-dichlorolichexanthone (major), 2,4,5-trichlorolichexanthone (major), 2,4-dichlorolichexanthone (trace), 2-chlorolichexanthone (minor), 4,5-dichloro-lichexanthone (trace), 2' -O-methylperlatolic acid (minor), 2-Omethylperlatolic acid (minor).

Pertusaria elliptica is characterised by the three to four rough spores per ascus, the conspicuous black ostioles and the chemistry. The species was previously reported to contain 4,5-dichlorolichexanthone (Archer 1991a) but liquid chromatography has shown the presence of the complex xanthone mixture listed above. Pertusaria elliptica occurs in northern Western Australia, the Northern Territory, Queensland and New South Wales, and also in New Caledonia.

Also examined: Lord Howe Island: near junction of tracks to Mutton Bird Point and Intermediate Hill, $31^{\circ} 32^{\prime} 43^{\prime \prime} \mathrm{S}, 159^{\circ} 04^{\prime} 48^{\prime \prime} \mathrm{E}$, alt. $60 \mathrm{~m}$, on dead palm in dry lowland forest with basalt outcrops, Elix 32744, June 1992 (ANUC).

\section{Pertusaria howeana Archer \& Elix, sp. nov.}

Thallus flavo-olivaceus vel virido-flavus, areolatus et rimosus, superficies laevis et hebetata, isidiis et sorediis destitutis, corticola; apothecia verruciformia, conspicua, numerosa, dispersa, plano-hemisphaerica, basi constrictescentia et distortescentia, interdum plus flavida quam thallus, $0.8-1.5(-2.0) \mathrm{mm}$ diam.; ostiola inconspicua, nigra vel translucida, in verruca 1-2na; sporae 8nae, irregulariter biseriatae, ellipsoideae vel subfusiformes, $75-87 \mu \mathrm{m}$ longae, $30-35 \mu \mathrm{m}$ latae. Thallus arthothelin et 6-O-methylartothelin continens.

Type: Lord Howe Island: Neds Beach Road at Malabar Hill Track, 31 31 31 16" S, $159^{\circ}$ $03^{\prime} 50^{\prime \prime} \mathrm{E}$, alt. $10 \mathrm{~m}$, on crown of Cryptocarya in disturbed lowland forest, J.A. Elix 32889, 22 June 1992 (holo ANUC).

Thallus dull yellowish green to dull greenish yellow, areolate and cracked, surface smooth and dull, lacking soredia and isidia; corticolous; apothecia verruciform, conspicuous, numerous, scattered, flattened hemispherical, becoming constricted at the base and distorted, sometimes yellower than the thallus, $0.8-1.5(-2.0) \mathrm{mm}$ diam.; ostioles inconspicuous, black or translucent, 1(-2) per verruca; spores 8 per ascus, irregularly 2-seriate, ellipsoid to subfusiform, 75-87 $\mu \mathrm{m}$ long, 30-35 $\mu \mathrm{m}$ wide. Fig. 2.

Chemistry: $\mathrm{K}-, \mathrm{KC}+$ yellow orange, $\mathrm{C}+$ yellow orange, $\mathrm{Pd}-$; arthothelin (major), 6-Omethylarthothelin (major), 2,5-dichloronorlichexanthone (minor), 2,7-dichloronorlichexanthone (minor), 4,5-dichloronorlichexanthone (trace).

Pertusaria howeana is characterised by the 8 biseriate spores, the yellowish verrucae and the presence of polychlorinated norlichexanthone derivatives. It resembles Pertusaria bartlettii Archer \& Elix, described from New Zealand (Archer \& Elix 1994) but differs from that species in the absence of thiophanic acid and the presence of 6-O-methyl-arthothelin. Pertusaria howeana is known only from Lord Howe Island.

Also examined: Lord Howe Island: track to Little Island, near Salmon Beach, $31^{\circ} 33^{\prime}$ $30^{\prime \prime} \mathrm{S}, 159^{\circ} 04^{\prime} 30^{\prime \prime} \mathrm{E}$, alt. $5 \mathrm{~m}$, on dead tree in scrubby, partly disturbed forest, Elix 32668 , June 1992 (ANUC); near junction of tracks to Mutton Bird Point and Intermediate Hill, $32^{\circ} 32^{\prime} 43^{\prime \prime} \mathrm{S}, 159^{\circ} 04^{\prime} 48^{\prime \prime} \mathrm{E}$, alt. $60 \mathrm{~m}$, on dead palm in dry lowland forest with basalt outcrops, Elix 32746, June 1992 (ANUC); along track to Mutton Bird Point, $31^{\circ} 32^{\prime} 45^{\prime \prime} \mathrm{S}, 159^{\circ} 05^{\prime} 00^{\prime \prime} \mathrm{E}$, alt. $60 \mathrm{~m}$, on base of palm in dry lowland forest with basalt outcrops, Elix 32795, June 1992 (ANUC). 


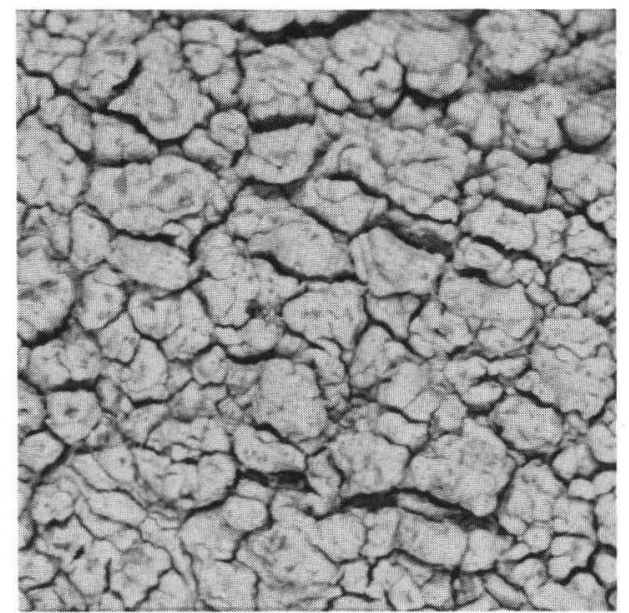

Figure 2. Pertusaria howeana, holotype, $\mathrm{X} 4$.

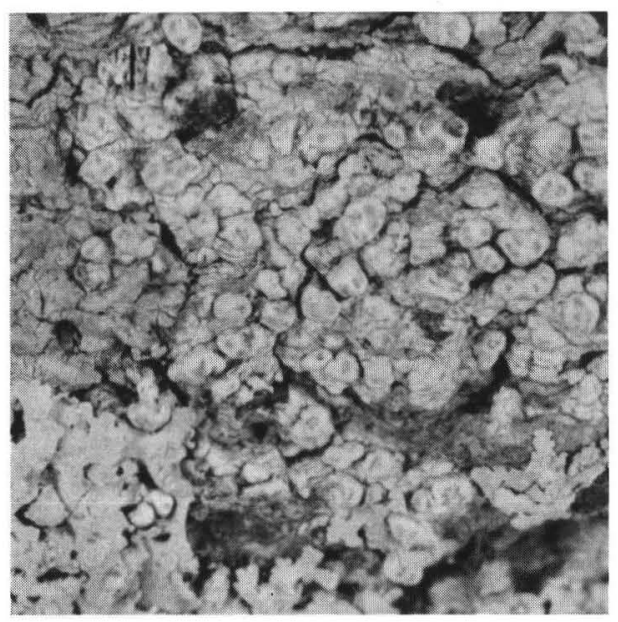

Figure 4. Pertusaria malabara, holotype, X 4.5.

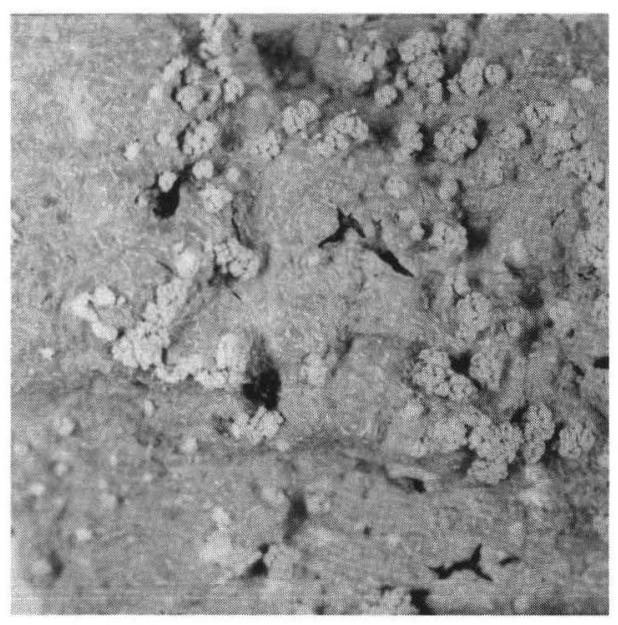

Figure 6. Pertusaria miniatescens, holotype, $\mathrm{X} 3$.

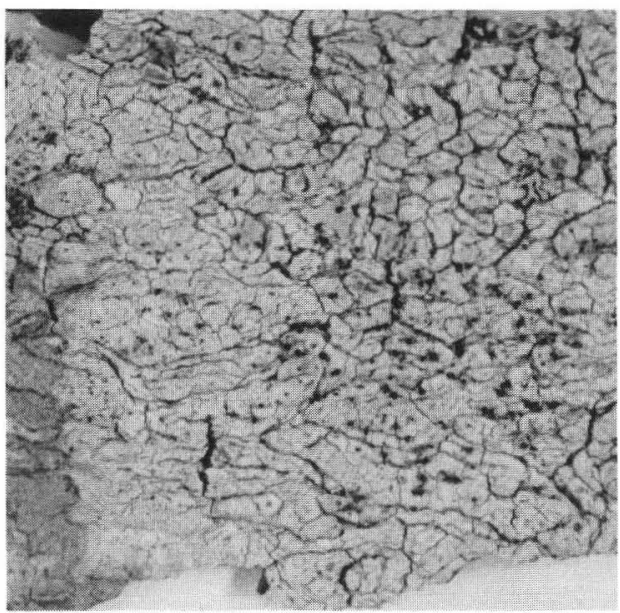

Figure 3. Pertusaria lordhowensis, holotype, X 4.

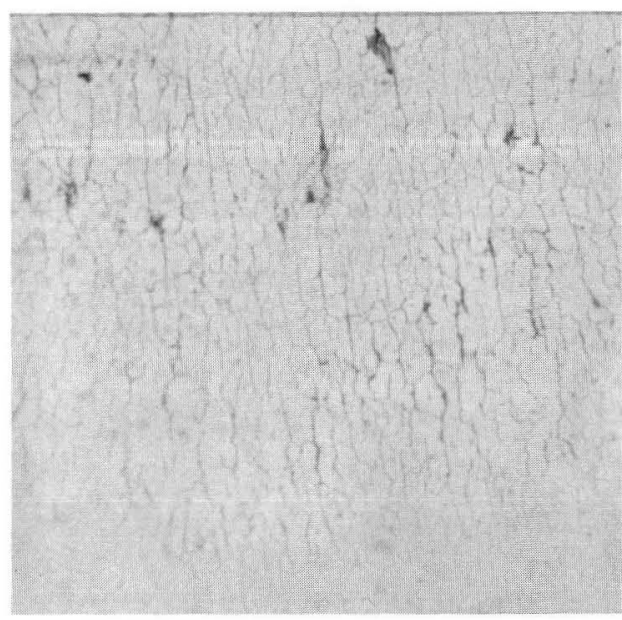

Figure 5. Pertusaria maritima, holotype, $\mathrm{X} 4$.

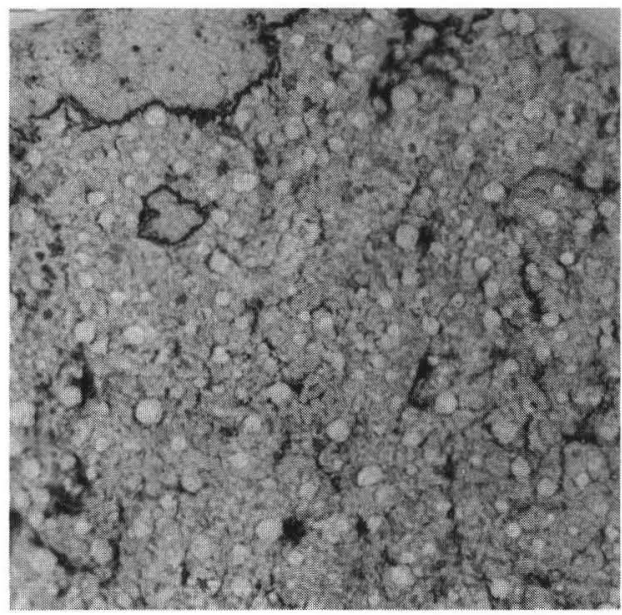

Figure 7. Pertusaria puffina, holotype, $X 3$. 
Pertusaria lavata Müll. Arg.

(Müller 1884: 462)

Type: New Zealand: s. loc., Knight s.n., 1883 (holo G).

Thallus pale greyish-white to pale fawn, thick, coarsely areolate and cracked, lacking isidia and soredia, surface smooth and dull, saxicolous; apothecia verruciform, numerous, crowded, often confluent, concolorous with the thallus, flattened hemispherical, $0.7-1.0 \mathrm{~mm}$ diam.; ostioles conspicuous, black, punctiform, surrounded by a pale translucent zone, 1 per verruca; spores 8 per ascus, usually $6-8$, ellipsoid to subfusiform, smooth, predominantly biseriate, 85-105 $\mu \mathrm{m}$ long, 30-40 $\mu \mathrm{m}$ wide.

Chemistry: K-, KC-, C-, Pd-; 4,5-dichlorolichexanthone and 2'-O-methylperlatolic acid.

Pertusaria lavata is characterised by the flattened verrucae (which are often confluent), the eight biseriate spores, flat ostioles and the chemistry. These morphological features distinguish $P$. lavata from the chemically similar, eight-spored saxicolous Pertusaria lophocarpa Körber (which also occurs in eastern Australia and New Zealand) and which has well-defined, rarely confluent verrucae, eight smaller uniseriate spores and conspicuously sunken ostioles. P. lavata occurs in eastern Australia and also in New Zealand.

Also examined: Lord Howe Island: along track to Mutton Bird Point, $32^{\circ} 32^{\prime} 45^{\prime \prime} \mathrm{S}$, $159^{\circ} 05^{\prime} 00^{\prime \prime} \mathrm{E}$, alt. $60 \mathrm{~m}$, on basalt rocks in dry lowland forest, Elix 32822, 32825, June 1992 (ANUC); between Little Island and The Cross, 31 $34^{\prime} 20^{\prime \prime} \mathrm{S}, 159^{\circ} 04^{\prime} 30^{\prime \prime} \mathrm{E}$, alt. $30 \mathrm{~m}$, on basalt rocks in Ficus dominated steep slope, Elix 33008, 33011, 33013, June 1992 (ANUC).

\section{Pertusaria leioplacella $\mathrm{Nyl}$.}

(Nylander 1867: 71)

Type: New Caledonia: Lifu, E. Marie s.n., 1863 (lecto H-NYL 23640, fide Awasthi \& Srivastava, isolecto H-NYL 23643).

Pertusaria amblyogona Müll. Arg. (Müller 1895: 638)

Type: Queensland: Toowoomba, Hartmann s.n., 1894 ( holo G).

Pertusaria confluens Müll. Arg. (Müller 1895: 638)

Type: Queensland: Toowoomba, Hartmann s.n., 1894 (holo G).

Thallus off-white to pale yellowish-white, areolate and cracked, surface smooth and dull, lacking isidia and soredia, corticolous; apothecia verruciform, numerous, scattered, sometimes confluent, flattened hemispherical, concolorous with the thallus, 0.5-1(-1.5) mm diam.; ostioles inconspicuous, translucent, pale yellow, 1 per verruca; spores 8 per ascus, usually 6-8, irregularly uni- or biseriate, ellipsoid, smooth, 52-72 $\mu \mathrm{m}$ long, 28-32 $\mu \mathrm{m}$ wide.

Chemistry: $\mathrm{K}-, \mathrm{KC}+$ orange, $\mathrm{C}+$ orange, $\mathrm{Pd}-$; thiophaninic and stictic acids with traces of hypostictic and constictic acids.

Pertusaria leioplacella is characterised by the pale yellow thallus giving a $\mathrm{KC}+$ and $\mathrm{C}+$ orange colour, the pale yellow ostioles and the eight spored asci. The species is distinguished from the somewhat similar Pertusaria gibberosa Müll.Arg. by the chemical reactions. The specimen from Lord Howe Island contained a relatively low concentration of thiophaninic acid compared to those found in specimens from eastern Australia. 
Pertusaria leioplacella occurs in the Northern Territory, eastern Queensland, New South Wales and Tasmania. It is widely distributed in the Southern Hemisphere in Brazil, Paraguay, South Africa, New Caledonia and Vanuatu, and also occurs in the West Indies, Mexico and Hawaii.

Also examined: Lord Howe Island: Neds Beach Road at Malabar Hill Track, $31^{\circ} 31^{\prime}$ $16^{\prime \prime} \mathrm{S}, 159^{\circ} 03^{\prime} 50^{\prime \prime} \mathrm{E}$, alt. $10 \mathrm{~m}$, on crown of Cryptocarya in disturbed lowland forest, Elix 32876, June 1992 (ANUC).

\section{Pertusaria limbata Vainio}

(Vainio 1890: 110)

Type: Brazil: Rio de Janeiro, E. Vainio, Lich. Bras. Exsicc. 208, 1885 (holo TUR-V 6719, iso UPS).

Pertusaria spaniostoma Vainio (Vainio 1926: 5)

Type: South Africa: Elsenburg, P.A. van der Byl 242 (holo TUR-V 34431).

Pertusaria simplex Vainio (Vainio 1929: 5)

Type: Mozambique: Palma, A. Pires de Lima 873, 1916 (holo TUR-V 34430).

Thallus pale olive green, areolate and cracked, surface smooth and dull, lacking isidia and soredia, corticolous; apothecia verruciform, flattened hemispherical, concolorous with the thallus, conspicuous, scattered, sometimes confluent, becoming constricted at the base, $0.7-1.2 \mathrm{~mm}$ diam.; ostioles inconspicuous, pale, translucent, 1-2 per verruca, sometimes fusing to form a sunken translucent disc; spores 8 per ascus, irregularly biseriate, ellipsoid to subfusiform, smooth, $65-75 \mu \mathrm{m}$ long, 25-30 $\mu \mathrm{m}$ wide.

Chemistry: K-, KC-, C-, Pd-; 2-chlorolichexanthone, stictic and constictic acids.

Pertusaria limbata is characterised by biseriate eight-spored asci and the presence of 2-chlorolichexanthone and stictic acid. It occurs in Queensland and New South Wales, and also in Brazil, Angola, Mozambique and South Africa.

Also examined: Lord Howe Island: Neds Beach Road at Malabar Hill Track, $32^{\circ} 31^{\prime}$ $16^{\prime \prime} \mathrm{S}, 159^{\circ} 03^{\prime} 50^{\prime \prime} \mathrm{E}$, alt. $10 \mathrm{~m}$, on crown of Cryptocarya in disturbed lowland forest, Elix 32881, June 1992 (ANUC).

Queensland: Moreton, Andrew Drynan Park, $4 \mathrm{~km}$ WNW of Richmond Gap, on Eucalyptus bark, Archer P 418, Sep 1992 (NSW).

New South Wales: North Coast, Border Ranges National Park, Antarctic Beech Lookout, on Solanum, Archer P 428, Sep 1992 (NSW).

\section{Pertusaria lordhowensis Archer \& Elix, sp. nov.}

Thallus albido-olivaceus, areolatus et rimosus, superficies laevis et hebetata, isidiis et sorediis destitutis, corticola; apothecia verruciformia, inconspicua, numerosa, dispersa, plano-hemisphaerica, thallo concoloria, 0.5-0.8 $\mathrm{mm}$ diam.; ostiola conspicua, atrobrunnea, singula in verruca; sporae 8nae, biseriatae, ellipsoideae, laeves, (50-) 60-75 $\mu \mathrm{m}$ longae, 25-30 $\mu \mathrm{m}$ latae. Thallus 2,4-dichloro-lichexanthone, 2,5-dichlorolichexanthone, 2,4,5-trichlorolichexanthone continens.

Type: Lord Howe Island: Neds Beach Road at Malabar Hill Track, $32^{\circ} 31^{\prime} 16^{\prime \prime} \mathrm{S}, 159^{\circ}$ $03^{\prime} 50^{\prime \prime} \mathrm{E}$, alt. $10 \mathrm{~m}$, on on crown of Cryptocarya in disturbed lowland forest, J.A. Elix 32878,22 June 1992 (holo ANUC). 
Thallus pale olive green, areolate and cracked, surface smooth and dull, lacking isidia and soredia; corticolous; apothecia verruciform, inconspicuous, numerous, scattered, flattened hemispherical, concolorous with the thallus, $0.5-0.8 \mathrm{~mm}$ diam.; ostioles conspicuous, dark brown, 1 per verruca; spores 8 per ascus, biseriate, ellipsoid, smooth, (50-)60-75 $\mu \mathrm{m}$ long, 25-30 $\mu \mathrm{m}$ wide. Fig. 3.

Chemistry: K-, KC-, C-, Pd-; 2-chlorolichexanthone (minor), 2,4-dichlorolichexanthone (major), 2,5-dichlorolichexanthone (major), 2,4,5-trichlorolichex anthone (major), with or without stictic acid (minor).

Pertusaria lordhowensis is characterised by the presence of chlorinated lichexanthones and asci with eight biseriate spores. The species is similar to the South American taxon, Pertusaria paraguayensis Müll. Arg. (Müller 1889) but differs in the hemispherical verrucae, very flattened in Pertusaria paraguayensis, and in chemistry; Pertusaria paraguayensis has 4,5-dichlorolichexanthone as a major compound in place of the 2-chlorolichexanthone present in Pertusaria lordhowensis. The new species is known only from the two specimens cited.

Also examined: Lord Howe Island: type locality, J.A. Elix 32873, June 1992 (ANUC).

\section{Pertusaria malabara Archer \& Elix, sp. nov.}

Thallus albido-olivaceus, subrimosus, superficies subtuberculata et hebetata, isidiis et sorediis destitutis, corticola; apothecia verruciformia, conspicua, numerosa, planohemisphaerica, basi constricta, thallo concoloria, $0.5-1 \mathrm{~mm}$ diam.; ostiola conspicua, flavida, translucida, concavescentia, $0.2-0.3 \mathrm{~mm}$ diam., in verruca $1-4 \mathrm{na}$; sporae 2 nae, ellipsoideae, laeves, 90-100 $\mu \mathrm{m}$ longae, 30-37 $\mu \mathrm{m}$ latae. Thallus 6-O-methylarthothelin et acida thiophanicum et sticticum continens.

Type: Lord Howe Island: Neds Beach Road at Malabar Hill Track, 31 31' 16" S, $159^{\circ}$ $03^{\prime} 50^{\prime \prime} \mathrm{E}$, alt. $10 \mathrm{~m}$, on crown of Cryptocarya in disturbed lowland forest, J.A. Elix 32875, 22 June 1992 (holo ANUC).

Thallus pale olive green, somewhat cracked, surface subtuberculate and dull, lacking isidia and soredia; corticolous; apothecia verruciform, conspicuous, numerous, flattened hemispherical, becoming constricted at the base, concolorous with the thallus, 0.5-1.0 mm diam.; ostioles conspicuous, pale yellow, translucent, becoming concave, $0.2-0.3 \mathrm{~mm}$ diam., 1-4 per verruca; spores 2 per ascus, ellipsoid, smooth, 90-100 $\mu \mathrm{m}$ long, 30-37 $\mu \mathrm{m}$ wide. Fig. 4.

Chemistry: $\mathrm{K}-, \mathrm{KC}+$ weak orange, $\mathrm{C}+$ weak orange, Pd-; stictic acid (minor), constictic acid (trace), thiophaninic acid (minor), arthothelin (trace), thiophanic acid (major), 6-O-methylarthothelin (major), 2,4-dichlorolichexanthone (trace) and 4,5dichlorolichexanthone (trace).

Pertusaria malabara is characterisd by the two-spored asci and the chemistry. It resembles the two-spored Pertusaria saltuensis Archer \& Elix from Queensland (Archer \& Elix 1992) but is distinguished from that species by the presence of 6-O-methylarthothelin as a major lichen compound and the translucent ostioles. The new species is known only from the type specimen.

The epithet 'malabara' refers to Malabar Hill, the type locality.

\section{Pertusaria maritima Archer \& Elix, sp. nov.}

Thallus albo-flavidus vel griseo-flavidus, tenuis, nonnihil areolatus et rimosus, superficies laevis et hebetata, isidiis destitutis, sorediatis, corticola; soralia flava, dispersa, subimmersa, $0.2-0.5 \mathrm{~mm}$ dia.; apothecia non visa. Thallus acida thiophaninicum et sticticum continens. 
Type: Lord Howe Island: near junction of tracks to Mutton Bird Point and Intermediate Hill, $31^{\circ} 32^{\prime} 43^{\prime \prime} \mathrm{S}, 159^{\circ} 04^{\prime} 48^{\prime \prime} \mathrm{E}$, alt. $60 \mathrm{~m}$, on dead palm in dry lowland forest with basalt outcrops, J.A. Elix 32765, 21 June1992 (holo ANUC).

Thallus pale yellowish grey to pale yellow, thin, somewhat areolate and cracked, surface smooth and dull; sorediate, lacking isidia; corticolous; soralia yellow, scattered, slightly immersed, $0.2-0.5 \mathrm{~mm}$ diam.; apothecia and spores not seen. Fig. 5.

Chemistry: $\mathrm{K}-, \mathrm{KC}+$ weak orange, $\mathrm{C}+$ weak orange, $\mathrm{Pd}-$; stictic acid (minor), thiophaninic acid (major), 2-chloro-6-O-methylnorlichexanthone (minor), 4-chloro-6-Omethylnorlichexanthone (trace).

Pertusaria maritima is characterised by the pale yellow to yellow thallus with scattered yellow soralia and in this respect it somewhat resembles the saxicolous Pertusaria persulphurata Müll. Arg. The slightly immersed soralia, the paler yellow thallus and the absence of lichexanthone distinguish the new species from Pertusaria persulphurata which lacks immersed soralia and contains lichexanthone. The new species also occurs in coastal New South Wales.

Also examined: New South Wales: North Coast: Hat Head National Park, c. $25 \mathrm{~km}$ ENE of Kempsey, 31 04' S, 153 03' E, alt. 100 m, on Banksia, Archer P 385, Sep 1992 (NSW); Myall Lakes National Park, Mungo Brush Camping area, near Bombah Broadwater, Myall River, on Erythrina, Archer P387, Sep 1992 (ANUC, NSW); Kattang Nature Reserve, Fishermans Bluff, $31^{\circ} 39^{\prime}$ E, $152^{\circ} 51^{\prime}$ E, alt. $80 \mathrm{~m}$, on Banksia, Archer P607, Oct 1993 (NSW); S side of Queens Lake near Laurieton, $31^{\circ} 38^{\prime} \mathrm{S}, 152^{\circ} 45^{\prime} \mathrm{E}$, alt. $2 \mathrm{~m}$, on Casuarina, Archer P614, Oct 1993 (NSW); Crowdy Bay National Park, Indian Head, $31^{\circ} 45^{\prime} \mathrm{S}, 152^{\circ} 50^{\prime} \mathrm{E}$, alt. $90 \mathrm{~m}$, on dead Banksia, Archer P632, Oct 1993 (NSW).

\section{Pertusaria miniatescens Archer $\mathcal{E}$ Elix, sp. nov.}

Thallus olivaceus, perrimosus, superficies laevis et nitida, isidiis destitutis, sorediata; saxicola; soralia conspicua, numerosa, thallo concoloria, subsphaerica, 0.5-2.0 $\mathrm{mm}$ diam.; apothecia non visa. Thallus acidum norsticticum continens.

Type: Lord Howe Island: Max Nicholls Track, 31 31' 08' S, $159^{\circ} 03^{\prime} 03^{\prime \prime} \mathrm{E}$, alt. $50 \mathrm{~m}$, on basalt rocks in dry lowland forest, J.A. Elix 32728, 20 June 1992 (holo ANUC).

Thallus olive green, conspicuously cracked, surface smooth and shiny, lacking isidia, sorediate; saxicolous; soralia conspicuous, numerous, concolorous with the thallus, subspherical, 0.5-2.0 mm diam.; apothecia and spores not seen. Fig. 6 .

Chemistry: K+ red, KC-, C-, Pd+ yellow; norstictic acid.

Pertusaria miniatescens is characterised by the olive green sorediate thallus containing norstictic acid. The presence of norstictic acid distinguishes the taxon from other sorediate species of Pertusaria on Lord Howe Island. The new species is the sterile, sorediate analogue of the fertile, esorediate Pertusaria patagonica Müll. Arg. (J. Müller 1889: 144), described from Argentina, and the two species form a species pair, sensu Poelt $(1970,1972)$. The olive green thallus distinguishes the new taxon from the white, sorediate, sterile saxicolous taxa Pertusaria excludens Nyl. [with norstictic acid] and Pertusaria teneriffensis Vainio [with norstictic and picrolichenic acids]. The new species is known only from the two specimens cited.

The epithet 'miniatescens' refers to the red colour produced with alkali, due to the presence of norstictic acid.

Also examined: Lord Howe Island: type locality, J.A. Elix 32733, June 1992 (ANUC). 


\section{Pertusaria montpittensis Archer}

(Archer in Elix et al. 1992: 65)

Type: Norfolk Island: Mt Pitt Reserve, Mt Bates summit trail, on Elaeodendron, in mixed subtropical rainforest, $29^{\circ} 00^{\prime} \mathrm{S}, 167^{\circ} 56^{\prime} 30^{\prime \prime} \mathrm{E}$, alt. $300 \mathrm{~m}$, J.A. Elix 18641, Dec 1984 (holo ANUC).

Thallus pale olive-green to pale yellow-grey, thin, continuous, surface smooth and shiny, copiously isidiate away from the margin; corticolous and saxicolous; isidia concolorous with the thallus, simple, branched or becoming coralloid, narrow at the base and swelling somewhat at the tip, 0.4-1.0 $\mathrm{mm}$ tall, 0.2-0.5 $\mathrm{mm}$ diam.; apothecia and spores not seen. Fig. 7.

Chemistry: K-, KC-, C-, Pd-; 4,5-dichlorolichexanthone, stictic and constictic acids and skyrin.

Pertusaria montpittensis is characterised by the isidiate thallus, the absence of verrucae and the chemistry. The holotype from Norfolk Island is corticolous but in Lord Howe Island it is both corticolous and saxicolous, occuring on basalt rocks. The species also occurs in eastern Queensland, Papua New Guinea and Tonga as the corticolous form.

Also examined: Lord Howe Island: track to Little Island, near Salmon Beach, $31^{\circ} 33^{\prime}$ $30^{\prime \prime} \mathrm{S}, 159^{\circ} 04^{\prime} 30^{\prime \prime} \mathrm{E}$, alt. $5 \mathrm{~m}$, in scrubby, partly disturbed lowland forest, Elix 32692, 32702 , 32706, June 1992 (ANUC); along ridge to Malabar Hill, 31 $31^{\prime} 16^{\prime \prime} \mathrm{S}, 1^{\circ} 9^{\circ} 03^{\prime}$ $50 " \mathrm{E}$, alt. $80 \mathrm{~m}$, in dense shrubby vegetation, Elix 32902, 32920, 32987, June 1992 (ANUC); ibid. on buttress roots of Ficus in dense shrubby vegetation, Elix 32955, June 1992 (ANUC).

Papua New Guinea: West New Britain: Willaumez Peninsula $20 \mathrm{~km}$ NNE of Talasea, $5^{\circ} 07^{\prime} \mathrm{S}, 150^{\circ} 07^{\prime} \mathrm{E}$, sea-level, on Baringtonia, Kolema 38, Dec 1984 (CBG 9311284).

Tonga: Eua: Ana Afu, alt. 350 m, on Ngatata, Child 1746, 1748, Jan 1971 (CHR 448487, 448483).

Pertusaria persulphurata Miill. Arg.

(Müller 1891: 391)

Type: Queensland: Brisbane, F.M. Bailey s.n. (holo G).

Pertusaria sulphurata Müll. Arg. (Müller 1893: 125)

Type: Queensland: Brisbane, F.M. Bailey s.n., 1891 (holo G).

Thallus thick or thin, pale to bright yellow, areolate and cracked, surface smooth and dull, lacking isidia, with sparse to numerous scattered yellow soralia; apothecia absent.

Chemistry: $\mathrm{K}-, \mathrm{KC}+$ orange-red, $\mathrm{C}+$ orange, $\mathrm{Pd}$ - or Pd+ weak yellow; thiophaninic and stictic acids with or without lichexanthone. The chemistry of Pertusaria persulphurata was reported in detail by Elix et al. (1978).

Pertusaria persulphurata is characterised by the yellow, sorediate thallus, lacking verrucae and spores. It is the sterile counterpart of Pertusaria xanthoplaca Müll. Arg. and somewhat resembles Pertusaria maritima. Pertusaria persulphurata occurs in eastern Australia as a common and conspicuous species on exposed rock, often found with the white, sorediate Pertusaria subventosa Malme. Pertusaria persulphurata also occurs in New Zealand (Archer \& Elix 1993). 
Also examined: Lord Howe Island: s. loc., J. Stovold, s.n., May 1924 (NSW); along ridge to Malabar Hill, $31^{\circ} 31^{\prime} 16^{\prime \prime} \mathrm{S}, 159^{\circ} 03^{\prime} 50^{\prime \prime} \mathrm{E}$, alt. $80 \mathrm{~m}$, on basalt rocks in dense shrubby vegetation, Elix 32965, June 1992 (ANUC).

\section{Pertusaria petrophyes Knight}

(Knight 1882: 47).

Type: New South Wales: near Sydney, C. Knight s.n. (holo WELT, iso H-NYL 23608).

Pertusaria leucoxantha Müll. Arg. (Müller 1895: 637).

Type: Queensland: Thursday Island, C. Knight 280, 1887 (holo G).

Thallus pale fawn or pale dull yellowish green, thin to effuse, surface smooth and dull, lacking isidia and soredia; apothecia verruciform, sparse to numerous, sometimes confluent, flattened hemispherical or irregular in outline, $0.5-1.5 \mathrm{~mm}$ wide; ostioles black, 1-2 per verruca, sometimes raised; spores 8 per ascus, hyaline, irregularly uniseriate, ellipsoid, smooth, 60-85 $\mu \mathrm{m}$ long, 25-45 $\mu \mathrm{m}$ wide.

Chemistry: $\mathrm{K}-, \mathrm{KC}+$ weak orange, $\mathrm{C}+$ weak orange, $\mathrm{Pd}-$; thiophaninic and 2-Omethylperlatolic acids with traces of 2-chloro-6-O-methylnorlichexanthone.

Pertusaria petrophyes is characterised by the eight-spored asci and the presence of thiophaninic and 2-O-methylperlatolic acids. Although both Pertusaria petrophyes and Pertusaria persulphurata contain thiophaninic acid, the latter species is bright yellow when compared with the dull yellowish green thallus of Pertusaria petrophyes. Pertusaria petrophyes occurs in eastern New South Wales and Queensland and also on the North Island of New Zealand.

The reported type locality of Pertusaria leucoxantha, which is morphologically and chemically identical to Pertusaria petrophyes, is probably an error (Archer \& Elix 1993) as no subsequent specimens of Pertusaria petrophyes have been collected north of latitude $26^{\circ} \mathrm{S}$.

Also examined: Lord Howe Island: along ridge to Malabar Hill, $31^{\circ} 31^{\prime} 16^{\prime \prime} \mathrm{S}, 159^{\circ}$ $03^{\prime} 50^{\prime \prime} \mathrm{E}$, alt. $80 \mathrm{~m}$, on basalt rocks in dense shrubby vegetation, Elix 32966, 32972, 32983, June 1992 (ANUC).

\section{Pertusaria puffina Archer \& Elix, sp. nov.}

Thallus subflavidus, tenuis, rimosus, superficies laevis et nitida, isidiis destitutis, sorediatus, saxicola; soralia alba, numerosa, dispersa, disciformia, $0.4-0.8 \mathrm{~mm}$ diam.; apothecia non visa. Thallus 2,4-dichlorolichexanthone, 2,4,5-trichlorolichexanthone et acidum sticticum continens.

Type: Lord Howe Island: along track to Mutton Bird Point, $31^{\circ} 32^{\prime} 45^{\prime \prime} \mathrm{S}, 159^{\circ} 05^{\prime} 00^{\prime \prime}$ $\mathrm{E}$, alt. $60 \mathrm{~m}$, on basalt rocks in dry lowland forest, J.A. Elix 32823, June 1992 (holo ANUC).

Thallus dull yellow, thin, cracked, surface smooth and shiny; saxicolous; lacking isidia, sorediate; soralia white, numerous, scattered, disciform, $0.4-0.8 \mathrm{~mm}$ diam.; apothecia and spores not seen. Fig. 7.

Chemistry: K-, KC-, C-, Pd-; stictic acid (major), constictic acid (minor), 2,5-dichlorolichexanthone (major), 2-chlorolichexanthone (minor), 2,4,5-trichlorolichexanthone (major), 2,4-dichlorolichexanthone (major).

Pertusaria puffina is characterised by the dull yellow thallus with scattered white soralia and the chemistry. The colour and chemistry distinguish the new species 
from Pertusaria persulphurata. A similar, un-named sorediate, corticolous species (with stictic acid replaced by 2-O-methylperlatolic acid) occurs on Norfolk Island (CBG 9201720).

The epithet 'puffina' is derived from Puffinus, the genus to which the mutton birds belong, a reference to Mutton Bird Point, the type locality.

Also examined: Lord Howe Island: Max Nicholls Track, $31^{\circ} 31^{\prime} 08^{\prime \prime} \mathrm{S}, 1^{\circ} 09^{\circ} 03^{\prime \prime} \mathrm{E}$, alt. $50 \mathrm{~m}$, on basalt rocks in dry lowland forest, Elix 32723, June 1992 (ANUC); type locality, Elix 32828, June 1992 (ANUC).

\section{Pertusaria schizostomella Müll. Arg.}

(Müller 1895: 637).

Type: New South Wales: s. loc., C. Knight 31, 1887 (holo G).

Thallus pale yellowish green to pale greyish green, slightly or coarsely areolate and cracked, surface smooth or very slightly rough, dull, lacking isidia and soredia, corticolous; apothecia verruciform, conspicuous, scattered or crowded and becoming confluent, concolorous with the thallus, slightly flattened hemispherical, not constricted at the base, $0.5-1 \mathrm{~mm}$ diam.; ostioles conspicuous, pale, translucent, dull yellow, usually one per verruca; spores 2 per ascus, ellipsoid, smooth, or very slightly rough, $80-125 \mu \mathrm{m}$ long, 30-45 $\mu \mathrm{m}$ wide.

Chemistry: $\mathrm{K}-, \mathrm{KC}+$ orange, $\mathrm{C}+$ orange, $\mathrm{Pd}-$; thiophaninic acid (major), stictic acid (major) with constictic acid (minor-trace).

Pertusaria schizostomella is characterised by the yellowish thallus, the two-spored asci and the presence of thiophaninic and stictic acids. It is distinguished from the very similar Pertusaria thiospoda by the translucent ostioles and the usually slightly rough spore walls. The species is common in eastern coastal Australia and also occurs on Norfolk Island and the North Island of New Zealand.

Also examined: Lord Howe Island: track to Little Island, near Salmon Beach, $31^{\circ} 33^{\prime}$ $30^{\prime \prime} \mathrm{S}, 159^{\circ} 04^{\prime} 30^{\prime \prime} \mathrm{E}$, alt. $5 \mathrm{~m}$, on Pandanus in scrubby, partly disturbed lowland forest, Elix 32678, June 1992 (ANUC); near junction of tracks to Mutton Bird Point and Intermediate Hill, $31^{\circ} 32^{\prime} 43^{\prime \prime} \mathrm{S}, 159^{\circ} 04^{\prime} 48^{\prime \prime} \mathrm{E}$, alt. $60 \mathrm{~m}$, on dead palm in dry lowland forest with basalt outcrops, Elix 32767, June 1992 (ANUC); along track to Mutton Bird Point, $31^{\circ} 32^{\prime} 45^{\prime \prime} \mathrm{S}, 159^{\circ} 05^{\prime} 00^{\prime \prime} \mathrm{E}$, alt. $60 \mathrm{~m}$, on dead canopy branches in dry lowland forest with basalt outcrops, Elix 32788, June 1992 (ANUC); Valley of Shadows, $31^{\circ} 31^{\prime} 45^{\prime \prime} \mathrm{S}, 159^{\circ} 04^{\prime} 45^{\prime \prime} \mathrm{E}$, alt. $40 \mathrm{~m}$, on fallen canopy branches of Cryptocarya in dry lowland forest on gentle slope, Elix 32840, 32841, June 1992 (ANUC); NNW of Middle Beach, $31^{\circ} 31^{\prime} 33^{\prime \prime} \mathrm{S}, 159^{\circ} 04^{\prime} 22^{\prime \prime} \mathrm{E}$, alt. $25 \mathrm{~m}$, on old fence posts in exposed, grazed grassland, Elix 32853, June 1992 (ANUC); Middle Beach, 31 31' 42" $\mathrm{S}, 159^{\circ} 04^{\prime} 30^{\prime \prime} \mathrm{E}$, alt. $3 \mathrm{~m}$, on shrubs along cliff face behind beach, Elix 32756b, June 1992 (ANUC).

\section{Pertusaria sublacerans Archer}

(Archer 1991: 242).

Type: Lord Howe Island: top of Intermediate Hill, $31^{\circ} 33^{\prime} \mathrm{S}, 159^{\circ} 06^{\prime} \mathrm{E}$, on old banyan tree, W.W. Watts s.n., July 1911 (holo NSW L5219).

Thallus dull olive green, thin, somewhat areolate and cracked, surface smooth and shiny, isidia and soredia absent, becoming pustulate, the pustules conspicuous, numerous, at first subisidioid, becoming hemispherical to subspherical, $0.5-1.5 \mathrm{~mm}$ diam., the upper part opening to reveal the white medulla; corticolous; apothecia 
disciform, somewhat sunken, the disc white pruinose $0.5-1 \mathrm{~mm}$ diam.; asci elongate-clavate, $c a .50 \times 200 \mu \mathrm{m}$, spores rare, one per ascus, ellipsoid, smooth 150 $175 \mu \mathrm{m}$ long, 60-70 $\mu \mathrm{m}$ wide, spore wall c. $1 \mu \mathrm{m}$ thick.

Chemistry: $\mathrm{K}+$ red, $\mathrm{KC}-, \mathrm{C}-, \mathrm{Pd}+$ yellow; norstictic acid.

Pertusaria sublacerans is characterised by the pustulate, dull olive green thallus and the presence of norstictic acid. It is distinguished from Pertusaria miniatescens by the esorediate thallus and the occasional disciform apothecia. The species also occurs on Norfolk Island.

Also examined: Lord Howe Island: Intermediate Hill, Watts s.n., July 1911 (NSW L4557); Erskine Valley, Watts s.n., Aug 1911 (NSW L4556).

Norfolk Island: Mt. Pitt, Mt. Pitt Reserve, $2^{\circ} 01^{\prime} \mathrm{S}, 167^{\circ} 56^{\prime} \mathrm{E}$, alt. $300 \mathrm{~m}$, on treelet stem, Streimann 34841 p.p., Dec 1984 (CBG9201721)

Pertusaria subrigida Müll. Arg.

(Müller 1895: 636).

Type: Queensland: Brisbane, F.M. Bailey 1570, 1891(holo G).

Pertusaria depressa (Fée) Mont. \& v.d. Bosch var. octomera Müll. Arg. (Müller 1884: 289)

Type: Brazil, Apiahy, Puiggiari 1470, 1882 (holo G).

Thallus pale olive green to pale greyish green, areolate and cracked, surface smooth to subtuberculate, dull, lacking isidia and soredia; corticolous; apothecia verruciform, conspicuous, scattered, flattened hemispherical, becoming constricted at the base, concolorous with the thallus, 1-2 mm diam.; ostioles inconspicuous, black, often sunken, 1-3 per verruca; spores 5-8 per ascus, irregularly uniseriate or biseriate, ellipsoid to fusiform, smooth, 70-110 $\mu \mathrm{m}$ long, 30-37 $\mu \mathrm{m}$ wide.

Chemistry: K-, KC-, C-, Pd-; no lichen compounds detected by thin-layer chromatography.

Pertusaria subrigida is characterised by the eight spored asci and the absence of lichen compounds. It occurs in eastern Queensland and New South Wales (Archer 1991a) and also Brazil. Pertusaria depressa var. octomera was reported from Main Range, Toowoomba' by Shirley (1893).

The species is uncommon in Australia and is known from only one specimen on Lord Howe Island.

Also examined: Lord Howe Island: along ridge to Malabar Hill, $31^{\circ} 31^{\prime} 16^{\prime \prime} \mathrm{S}, 159^{\circ}$ $03^{\prime} 50^{\prime \prime} \mathrm{E}$, alt. $80 \mathrm{~m}$, on shrub in dense shrubby vegetation with basalt outcrops, Elix 32944, June 1992 (ANUC).

Pertusaria subventosa Malme var. subventosa

(Malme 1936: 7).

Type: Brazil: Matto Grosso: Serra da Chapada, Buriti, G. Malme 3936, 24 June 1894 (holo S).

Pertusaria paeminosa Archer (Archer 1990: 395).

Type: New South Wales: Bairne track, c. $30 \mathrm{~km} \mathrm{~N}$ of Sydney, on exposed sandstone, A.Archer P 38, 14.i.1989 (holo NSW, iso CBG). 
Pertusaria sorediata Knight in Shirley [nom. illeg. non Pertusaria sorediata (Fr.) Fr. 1846] (Knight in Shirley 1889: 141).

Type: Queensland: Moreton Bay, J. Shirley 67 (holo WELT).

Thallus off-white to greyish white, thick, areolate and cracked, surface smooth, lacking isidia, sorediate, saxicolous; soralia white, conspicuous, becoming numerous and often confluent away from the margin, subspherical, sometimes slightly stipitate, $0.5-1.5 \mathrm{~mm}$ wide; apothecia very rare, disciform, discs dark brown, white pruinose, $0.2-0.5 \mathrm{~mm}$ diam., becoming exposed in stipitate soralia in groups of 1-3; spores solitary, elongate ellipsoid, rarely lachrymoid, sometimes slightly curved, 120-160 $\mu \mathrm{m}$ long, 35-50 $\mu \mathrm{m}$ wide, spore wall $1 \mu \mathrm{m}$ thick.

Chemistry: $\mathrm{K}+$ yellow, $\mathrm{KC}+$ violet, $\mathrm{C}-, \mathrm{Pd}+$ yellow; lichexanthone and picrolichenic and thamnolic acids.

Pertusaria subventosa is a common, conspicuous saxicolous species in eastern Australia, often found with Pertusaria persulphurata Müll. Arg., from sea-level to c. 1000 $\mathrm{m}$; it also occurs in Brazil and New Zealand. It resembles the northern hemisphere Pertusaria amara (Ach.) Nyl. but this species is predominantly corticolous and lacks lichexanthone and $\beta$-orcinol depsides such as thamnolic or hypothamnolic acids.

Also examined: Lord Howe Island: along ridge to Malabar Hill, $31^{\circ} 31^{\prime} 16^{\prime \prime} \mathrm{S}, 159^{\circ}$ $03^{\prime} 50^{\prime \prime} \mathrm{E}$, alt. $80 \mathrm{~m}$, on basalt rocks in dense shrubby vegetation, Elix 32952, June 1992 (ANUC).

New Zealand: North Island: Three Kings Islands, Great Island, Bald Hill, Galloway s.n., Nov 1970 (CHR 451398).

Pertusaria subventosa Malme var. deficiens Archer \& Elix

(Archer \& Elix 1993a: 146).

Type: Queensland: Great Dividing Range, Hughenden-Townsville Highway, $28 \mathrm{~km}$ SW of Pentland, $20^{\circ} 43^{\prime} \mathrm{S}, 145^{\circ} 14^{\prime} \mathrm{E}$, alt. $460 \mathrm{~m}$, on sandstone, J.A. Elix 20753, June 1986 (holo ANUC).

Pertusaria subventosa var. deficiens is morphologically identical to var. subventosa but lacks thamnolic acid.

Chemistry: $\mathrm{K}-, \mathrm{KC}+$ violet. $\mathrm{C}-, \mathrm{Pd}-$; lichexanthone and picrolichenic acid.

Pertusaria subventosa var. deficiens is less common than var. subventosa and occurs predominantly in Queensland (Archer \& Elix 1993a).

Also examined: Lord Howe Island: along ridge to Malabar Hill, $31^{\circ} 31^{\prime} 16^{\prime \prime} \mathrm{S}, 159^{\circ}$ $03^{\prime} 50^{\prime \prime} \mathrm{E}$, alt. $80 \mathrm{~m}$, on basalt rocks in dense shrubby vegetation, Elix 32993, June 1992 (ANUC).

\section{Pertusaria thiospoda Knight}

(Knight 1882:47).

Type: New South Wales: near Sydney, Knight 20 (holo WELT).

Thallus pale yellowish white to pale yellow, thin, slightly cracked, surface smooth and dull, isidia and soredia absent; corticolous; apothecia verruciform, inconspicuous, scattered, sometimes confluent, flattened hemispherical, not constricted at the base, 0.5-1 mm diam.; ostioles pale brown to black, one per verruca; spores 2 per ascus, ellipsoid, smooth, 80-110(-120) $\mu \mathrm{m}$ long, 30-40 $\mu \mathrm{m}$ wide. 
Chemistry: $\mathrm{K}-, \mathrm{KC}+$ yellow orange, $\mathrm{C}+$ yellow orange, $\mathrm{Pd}-$; thiophaninic acid (major), stictic acid (major) and constictic acid (minor).

Pertusaria thiospoda is characterised by the two-spored asci and the presence of thiophaninic and stictic acids. It is distinguished from the similar Pertusaria schizostomella Müll. Arg. by the dark ostioles and spores with smooth walls. The species is common in eastern coastal New South Wales and also occurs on Norfolk Island (Elix et al. 1992).

Also examined: Lord Howe Island: track to Little Island, near Salmon Beach, $31^{\circ} 33^{\prime}$ $30^{\prime \prime} \mathrm{E}, 159^{\circ} 04^{\prime} 30^{\prime \prime} \mathrm{E}$, alt. $5 \mathrm{~m}$, on dead tree in scrubby, partly disturbed lowland forest, Elix 32666, June 1992 (ANUC); end of Anderson Road, 31 31' 46" S, $159^{\circ} 04^{\prime}$ $20^{\prime \prime} \mathrm{E}$, alt. $25 \mathrm{~m}$, on fallen canopy branches of Cryptocarya in disturbed lowland forest, Elix 32835, June 1992 (ANUC).

\section{Summary}

The lichen flora of Lord Howe Island contains 20 species in the genus Pertusaria; five of these appear to be endemic and 14 species also occur in Australia. Six of these also occur in New Zealand. (Table 1).

\section{Table 1. Distribution of Lord Howe Island Pertusaria}

Species

Lord Howe

Island
P. asperata
P. dehiscens
P. elliptica
P. howeana
P. lavata
P. leioplacella
P. limbata
$P$. lordhowensis
P. malabara
P. maritima
P. miniatescens
P. montpittensis
P. persulphurata
$P$. petrophyes
$P$. puffina
P. schizostomella
P. sublacerans
P. subrigida
$P$. subventosa
P. thiospoda

\section{Distribution}

Australia

Norfolk

Island

New

Zealand

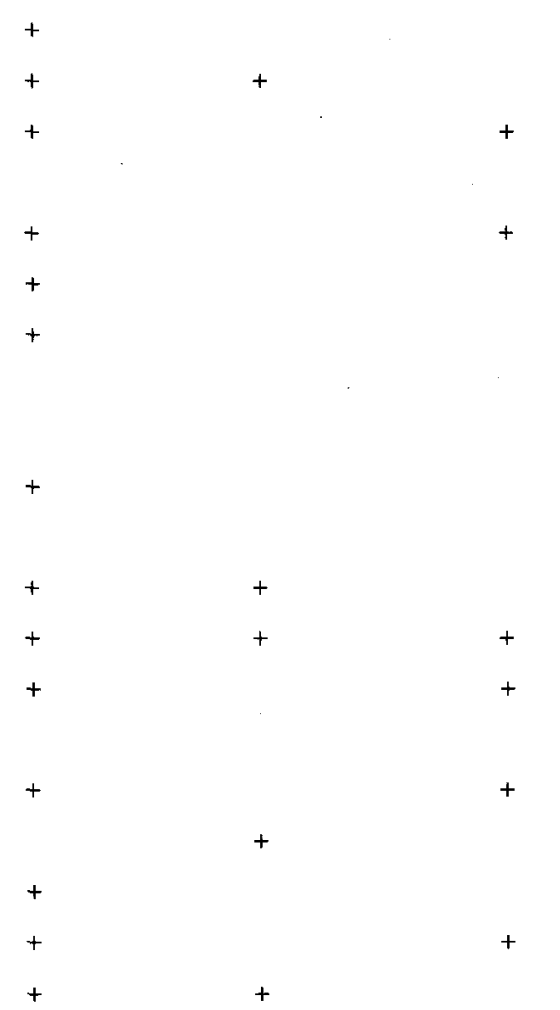


Some recent studies have reported the lichen flora of a number of islands in the same region as Lord Howe Island (Galloway \& Hayward 1987; Hayward et al. 1991; Elix et al. 1992; Hayward \& Lumbsch 1992) and these findings, for the genus Pertusaria, are summarised in Table 2. Lord Howe Island has a relatively large number of Pertusaria species when compared with other islands in the same region; the number of endemic taxa is also noteworthy (Table 2).

\begin{tabular}{|c|c|c|c|c|c|}
\hline \multirow{3}{*}{$\begin{array}{l}\text { Locality } \\
\text { Lord Howe Island }\end{array}$} & \multirow{2}{*}{\multicolumn{3}{|c|}{ Lat. Long. }} & \multicolumn{2}{|c|}{ Number of Pertusaria species } \\
\hline & & & & Total & Endemic \\
\hline & $31^{\circ} 32^{\prime} \mathrm{s}$ & $159^{\circ} 05^{\prime}$ & E & 20 & 5 \\
\hline Norfolk Island & $29^{\circ} 04^{\prime} \mathrm{S}$ & $167^{\circ} 55^{\prime}$ & $E$ & $10 \#$ & 3 \\
\hline Three Kings Islands & $34^{\circ} 06^{\prime} \mathrm{S}$ & $172^{\circ} 20^{\prime}$ & $E$ & $6^{*}$ & 0 \\
\hline Little Barrier Island & $36^{\circ} 12^{\prime} 5$ & $175^{\circ} 07^{\prime}$ & $\mathrm{E}$ & 5 & 0 \\
\hline Stewart Island & $47^{\circ} 10^{\prime} \mathrm{s}$ & $167^{\circ} 40^{\prime}$ & $E$ & 6 & 0 \\
\hline
\end{tabular}

\# Seven species were originally reported (Elix et al. 1992) and Pertusaria sublacerans Archer, Pertusaria globospora Archer and Pertusaria velata (Turn.) Nyl. have been identified in more recent collections from Norfolk Island.

* Five species were originally reported (Galloway \& Hayward 1987) and Pertusaria subventosa Malme has been identified in earlier collections from Three Kings Islands.

\section{Artificial key to Pertusaria in Lord Howe Island}

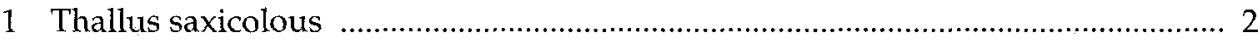

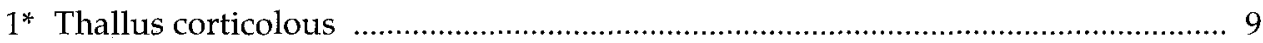

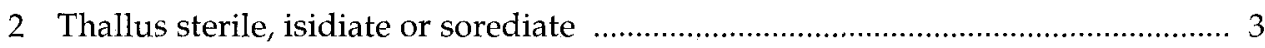

$2^{*}$ Thallus fertile, spores 8 per ascus, lacking isidia and soredia ........................... 7

3 Thallus isidiate; 4,5-dichlorolichexanthone and stictic acid

P. montpittensis

$3^{*}$ Thallus sorediate

4 Thallus white, UV bright yellow, $\mathrm{KC}+$ violet,

P. subventosa

$4^{*}$ Thallus yellow, dull yellow or olive green, UV bright or dull orange, $\mathrm{KC}+$ orange or -ve

5 Thallus olive green, soredia $\mathrm{K}+$ red, $\mathrm{Pd}+$ yellow P. miniatescens

$5^{*}$ Thallus yellow or dull yellow, soredia K-ve 6 
6* Thallus dull yellow, KC-ve

P. puffina

7 Thallus off-white, UV bright yellow, spores 100-125 $\mu \mathrm{m}$ long P. asperata

$7^{*}$ Thallus greyish-white or dull yellow green, UV dull orange 8

8 Verrucae $\mathrm{KC}+$ orange, spores $60-85 \mu \mathrm{m}$ long, thiophaninic acid ..... P. petrophyes $8^{*}$ Verrucae KC-, spores 85-105 $\mu \mathrm{m}$ long, 4,5-dichlorolichexanthone $P$. lavata

9 Thallus sorediate, yellow, sterile, $\mathrm{KC}+$ orange P. maritima

9* Thallus esorediate, fertile, apothecia disciform or verruciform 10

10 Apothecia disciform, $\mathrm{K}+$ red, $\mathrm{Pd}+$ yellow, spores uncommon, 1 per ascus, 150 $175 \mu \mathrm{m}$ long

P. sublacerans

$10^{*}$ Apothecia verruciform 11

11 Spores 2 per ascus, ca. $100 \mu \mathrm{m}$ long, stictic acid 12 $11^{*}$ Spores 4 or 8 per ascus 14

12 Spore wall rough, ostioles usually translucent P. schizostomella $12 *$ Spore wall smooth, ostioles black or translucent yellow 13

13 Ostioles black, thiophaninic acid

P. thiospoda $13^{*}$ Ostioles translucent yellow, thiophanic acid and 6-O-methylarthothelin P. malabara

14 Spores 4 per ascus, spore wall rough, spores $95-110 \mu \mathrm{m}$ long P. elliptica $14^{*}$ Spores 8 per ascus, predominantly biseriate 15

15 Spores $100-140 \mu \mathrm{m}$ long, lichexanthone present P. dehiscens $15^{*}$ Spores $<100 \mu \mathrm{m}$ long, lichexanthone absent 16

16 Verrucae $\mathrm{KC}+$ orange 17

$16^{*}$ Verrucae KC18

17 Spores 75-85 $\mu \mathrm{m}$ long, arthothelin and 6-O-methylarthothelin P. howeana $17^{\star}$ Spores $52-72 \mu \mathrm{m}$ long, thiophaninic acid P. leioplacella

18 Lichen compounds absent, spores $80-95 \mu \mathrm{m}$ long P. subrigida $18^{\star}$ Lichen compounds present, spores $<80 \mu \mathrm{m}$ long 


\section{Acknowledgements}

The authors are grateful to the Herbaria referred to above for the loan of specimens, to Mr D. Verdon for checking the Latin descriptions and to Mrs C. Barclay (nee Crook) for technical assistance with liquid chromatography; one of us (AWA) is grateful to the National Herbarium of New South Wales for arranging the loan of type and other specimens and for permission to use the facilities of the Herbarium; the other (JAE) gratefully acknowledges the Australian Research Council for generous financial support. We also wish to thank Mr Ian Hutton and the Australian Council of National Trusts for permitting us to use the map of Lord Howe Island (Figure 1) which appeared in Hutton (1985).

\section{References}

Archer, A.W. (1990) A new species in the lichen genus Pertusaria from the Southern Hemisphere: Pertusaria paeminosa. Nova Hedwigia 50: 395-399.

Archer, A.W. (1991) New species and new reports of Pertusaria (Lichenised Ascomycotina) from Australia and New Zealand with a key to the species in Australia. Mycotaxon 41: 223-269.

Archer, A.W. (1991a) Synonymy and chemotaxonomy of Australian Pertusaria species (Lichenes) based on Australian type specimens. Telopea 4(2): 165-184.

Archer, A.W. \& Elix, J.A. (1992) Further new species and new reports of Pertusaria (Lichenised Ascomycotina) from Australia. Mycotaxon 45: 417-431.

Archer, A.W. \& Elix, J.A. (1993) Saxicolous species of Pertusaria (Lichenes) common to New Zealand and Australia. New Zealand J. Bot. 31: 11-116.

Archer, A.W. \& Elix, J.A. (1993a) Additional new taxa and a new report of Pertusaria (Lichenised Ascomycotina) from Australia. Mycotaxon 49: 143-150.

Archer, A.W. \& Elix, J.A. (1994) Additional new species and new reports of Pertusaria (Lichenised Ascomycotina) from New Zealand with a revised key to the corticolous species in New Zealand. Mycotaxon 50: 203-217.

Cheel, E. (1906) Bibliography of Australian, New Zealand and South Sea lichens. J. E Proc. Roy. Soc. New South Wales 40: 141-154.

Cheel, E. (1913) Australasian and South Sea Stictaceae. Part II. Report of the 14th. Meeting Australasian Association for the Advancement of Science Melbourne 1913. 13: 311-320.

Elix, J.A, Musidlak, H.W., Sala, T. \& Sargent, M.V. (1978) Structure and synthesis of some lichen xanthones. Austral. J. Chem. 31: 145-155.

Elix, J.A., Streimann, H. \& Archer, A.W. (1992) The Lichens of Norfolk Island 2. The Genera Cladonia, Pertusaria, Pseudocyphellaria and Ramalina. Proc. Linn. Soc. New South Wales. 113(1): $57-76$.

Elix, J.A. \& Venables, D.A. (1993) 4-O-methyllividic acid, a new lichen compound. Mycotaxon 47: $275-281$.

Galloway, D.J. \& Hayward, B.W. (1987) Lichens from Three Kings Islands, Northern New Zealand. Rec. Auckland Inst. Mus. 24: 197-213.

Hayward, B.W., Wright, A.E \& Hayward, G.C. (1991) Lichens of Little Barrier Island (Hauturu), Northern New Zealand. Rec. Auckland Inst. Mus. 28: 185-199.

Hayward, B.W. \& Lumbsch, H.T. (1992) Lichens of South-East Stewart Island, New Zealand. New Zealand Natural Sciences 19: 69-78.

Hutton, I. (1985) Discovering Australia's World Heritage, Lord Howe Island. (Conservation Press: Canberra).

Knight, C. (1882) Contributions to the lichenographia of New South Wales. Trans. Linn, Soc. London, Bot. 2: 37-51.

Krempelhuber, A. von (1881 [1880]) Ein neuer Beitrag zur Flechten-Flora Australiens. Verh. K.K. Zool.-Bot. Ges. Wien 30: 329-342. 
Malme, G.O.A. (1936) Pertusariae Epeditionis Regellenianae primae. Ark. Bot. 28A: 1-27.

McDougal, I., B.J. Embleton and D.B. Stone (1981) Origin and evolution of Lord Howe Island, Southwest Pacific Ocean. J. Geol.Soc. Australia 28: 155-176.

Müller, J. (1884) Lichenologische Beiträge XIX. Flora 67: 268-274; 283-289; 299-306; 349-354; $396-402 ; 460-468$.

Müller, J. (1889) Lichenologische Beiträge XXXI. Flora 72: 142-147.

Müller, J. (1891) Lichenes Brisbanenses. Nuovo Giorn. Bot. Ital. 23: 385-404.

Müller, J. (1893) Lichenes Exotici II. Hedwigia 32: 120-136.

Müller, J. (1895) Lecanoreae et Lecideeae Australienses novae. Bull.Herb. Boissier 3: 632-642.

Nylander, W. (1867) Synopsis Lichenum Novae Caledoniae. Bull. Soc. Linn. Normandie, sér.2,2: $39-140$.

Pickard, J. (1973) An annotated botanical bibliography of Lord Howe Island.Contributions New South Wales Natl. Herb. 4: 470-491.

Pickard, J. (1981) Vegetation of Lord Howe Island. Cunninghamia 1: 133-265.

Poelt, J. (1970) Das Kozept der Artenpaare bei den Flechten. Deutsche Bot. Ges. N.F.4: 187-198.

Poelt, J. (1972) Die taxonomische Behandlung von Artenpaare bei den Flechten. Bot. Not. 125: 77-81.

Shirley, J.F. (1889) The lichen Flora of Queensland. Proc. Roy. Soc. Queensland 6: 138-145.

Shirley, J.F. (1893) in Bailey, F.M. Contributions to the Queensland Flora, Botany Bulletin VIII. Queensland Dept. Agric. Bull. (s.n.): 98-99.

Vainio, E.A. (1890) Etude sur la classification naturelle et la morphologie des lichens du Bresil. I. Acta Soc. Fauna Fl. Fenn. 7: 1-247.

Vainio, E.A. (1926) Lichenes africani novi. Ann. Univ. Fenn. Aboënsis, Ser. A, II, 3:1-33.

Vainio, E.A. (1929) Lichenes Mozambici. Bol. Soc. Brot., Ser.2, 6: 144-179.

Zahlbruckner, A. (1896) Lichenes Mooreani. Ann. K. K.Naturhist. Hofmus., 11: 188-196. 